\title{
White coat revisited
}

Previously published at www.cmaj.ca

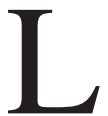
ike an infatuated old lover, she has returned to me. There was no mention of how I left her; no talk of how we hadn't seen each other for several years. She came back to me and now we are together. Inseparable: a family doctor and his white coat.

Ours is a long history. As a first-year medical student I yearned to be with her, I was jealous of those upper-year students who had already settled down. As the spring blossomed in my second year of medical studies, we took part in Canada's first white coat ceremony. We were pronounced étudiant-médecin et sarau, one of 136 monogamous unions between clean coats and even cleaner young optimists. Both would become sullied during the hardships of clerkship, but, as we had vowed, we would take each other to have and to hold, through sickness and health, in good times and bad.

Certainly, there were difficulties. Seams frayed at the end of 30-hour shifts. There was collateral damage from surgical suite spills. I am ashamed to admit that occasionally my eye wandered and that I spent one evening's call in the arms of a hospital loaner while my own coat lay lonely and forlorn in my apartment's washing machine. The loaner looked clean and inviting at first sight, but it was starchy and cold, and on closer inspection had more imperfections than I first thought. Guiltily, I returned to my mate, filled with secrets and new-found appreciation.

Then something happened. As I began my outpatient rotations, the white coat no longer seemed practical. There were questions of microbial transmission and now that I was out of the line of fire, the threat of bodily stains was lessened exponentially. Besides, the temperature at some of those offices was just too hot. Moreover, many of my preceptors went sans sarau; as an acolyte I soon followed
But something happened. Considering its laid-back, Pacific reputation, I thought that Vancouver, British Columbia, would be a town of medical bachelors, a place where doctors bared their collared dress shirts. I was wrong. When not skiing and hiking and yoga-ing, doctors worked hard - and they worked hard in their white coats. Walk-in and full-service clinics alike presented a homogenous army of uniformed physicians. I was suddenly an outsider, a single guy at a dance for couples.

The patients noticed as well. I have looked 25 years old for the past 15 years and it was catching up to me. "I've never had a doctor who could be my grandson," remarked one patient. (To which I replied: "Mrs. Goldstein, you're only 38.") I thanked others for complimenting me on my youthful appearance and stated that I hoped it would inspire them to adopt similarly healthy lifestyles.

However, it gradually occurred to me that people

suit. I rationalized that because my casual attire was closer to that of my patients, perhaps we could enter more easily into the therapeutic partnership that is a pillar of family medicine.

Years lapsed. I sometimes thought of her, but I was so immersed in my training that her absence was rarely felt. We got back together for a twomonth fling during my obstetrics rotation, but we both knew that it was a relationship of convenience to keep us warm during the long Montréal winter and amniotic fluid-filled nights.

I moved on, literally. After finishing my residency and passing my licensing exams, I relocated to the west coast. I was a fresh face, a single family doctor with a licence, and I was ready for the swinging lifestyle of family practice. wanted to know that their doctor was capable of a long-term relationship. So now we are once again inseparable, my white coat and I, sharing experiences and meeting people together, as a couple. Patients look at us approvingly and see how happy we are ... at least until the next fight over laundry.

\section{Eric Cadesky MD CM}

Clinical instructor

Department of Family Medicine University of British Columbia Vancouver, BC

Have you got an opinion about this arti-
cle? Post your views at www.cmaj.ca.
Potential Salon contributors are welcome
to send a query to salon@cmaj.ca.

Have you got an opinion about this artiPotential Salon contributors are welcome to send a query to salon@cmaj.ca.

All editorial matter in CMAJ represents the opinions of the authors and not necessarily those of the Canadian Medical Association. 